Miodrag Cvetković1

City Administration, Leskovac

Maja Ranđelović ${ }^{2}$

Raica Milićević ${ }^{3}$

Viša poslovna škola za ekonomiju i preduzetništvo, Beograd
SCIENTIFIC REVIEW ARTICLE

DOI:10.5937/ekonomika1703097C

Received: Jun, 07, 2017

Accepted: Jun, 29, 2017

\title{
APPARENT CONTRADICTIONS EFFECTIVE AND EFFICIENT SUPPLY CHAIN - TIME PRESSURE AND ELIMINATING THE STOCK
}

\begin{abstract}
Responsive performance as a response to all the requirements of customers and consumers, at first glance, requires plenty of time and a high level of inventories in order to service the customers and consumers in a quality manner. However, in recent decades, along with the development of the concept of supply chain, in theory and in practice, proves the opposite: in conditions of the high level of competition and the speed of change in the needs and demands of consumers, the speed of orders execution is often the key performances in many supply chains. As regards inventory, competitive supply chain tends to hold stocks only for the needs of production during or even minimum safety stocks over it. Companies are trying to organize their supply chains so as to achieve the quality, completeness and reliability of delivery in the shortest possible time and with minimal inventory. Such operational capability is achieved and the efficiency and competitiveness of the supply chain, that is, "operational excellence" can be solve contradiction of the time compression and the stock reduction, compared to the total satisfaction of customers. This paper will be discussed models, methods and techniques of management in the supply chain that allow such an organization.
\end{abstract}

Keywords: Supply Chain, time pressure, reduction of inventories, efficiency, konkurentnokst.

JEL classification: M21, L21, F60

\section{ПРИВИДНЕ КОНТРАДИКЦИЈЕ ЕФЕКТИВНОГ И ЕФИКАСНОГ ЛАНЦА СНАБДЕВАЫА - ВРЕМЕНСКИ ПРИТИСАК И ЕЛИМИНИСАЊЕ ЗАЛИХА}

\section{Апстракт}

Респонзивност као перформанса одазива на све захтеве купаца и потрошача, на први поглед захтева довољно времена и висок ниво залиха да би се

\footnotetext{
${ }^{1}$ cvetkovic.miodrag2803@gmail.com

2 majaranđelovic@gmail.com

${ }^{3}$ raica.milicevic@nisparking.rs
} 
купци и потрошачи сервисирали на квалитетан начин. Међутим, последњих деценија, упоредо са развојем кониепта ланца снабдевања, у теорији и пракси доказује се супротно: у условима високог нивоа конкуренције и брзине промена потреба и захтева потрошача, брзина извриења проручбина је често кључна перформанса у многим ланцима снабдевања. Што се залиха тиче, конкурентан ланац снабдевања тежи да држи залихе само за потребе производње у току или још и минималне сигурносне залихе преко тога. Компаније настоје да своје ланце снабдевања организују тако да остваре квалитет, комплетност и поузданост испоруке у што краћем времену и са што мањим залихама. Таквом оперативном способношћу остварује се и ефикасност и конкурентност ланца снабдевања, односно, „оперативна изврсност “може решити контрадикције временског притиска и редукције залиха у односу на потпуну сатаисфакцију купаца. У овом раду ће бити разматрани модели, методе и технике управљања у ланиу снабдевања који омогућавају такву организацију.

Кључне речи: Ланац снабдевања, временски притисак,редукиија залихе, ефикасност, конкурентнокст.

\section{Introduction}

Modern business conditions in recent decades, characterized by the expansion of the globalization process, the development of information and communication technologies we, changing consumer behavior and increase competition, demanded radical changes in business organization. This has led to the development of a process approach instead of a functional and to the development and application of the concept of the supply chain as a response to the present operating conditions. Supply chain organization (or reorganization of existing) required re-engineering of business processes, that is, analysis that can come to the conclusion that it is necessary that some of the activities and processes must be radically changed or even eliminated. Process re-engineering may require extinguishing even the organizational unit (for example, some storage facilities) or move some activities and processes in other strategic business unit, even with the partners (the other company). The concept of supply chain such changes are not unusual, on the contrary. The essence of a competitive supply chain is achieved very often radical changes in strategic focus, dramatic change in the organization and reorganization of business processes.

The process of the supply chain regulates the required level of capacity and enterprise resource because it uses only the capacity level required for the process of meeting the demand in a particular market segment being serviced. Excess capacity and resources is the problem of the enterprise and can be incorporated into other supply chain or it can be removed (to eliminate). In this way, the essence of its supply chain concept of regulating profitability of companies in the chain, as opposed to the functional organization where it is difficult to determine what is rational behavior in the functional departments of the company. 
In many companies time to control, but above all in key processes that a company with its core competence adds the highest value, and neglect are not core activities that can be a source of irrationality and inertia or may be a bottleneck where the process stops (for example, this can be process expeditions in the department of sales and maintenance of equipment, etc.). In operating the process of integration of logistics activities and processes established synchronization and continuous flow of materials, goods and information, but are necessary models, methods and management techniques in order to guide the process, achieve coordination between the activities and processes of partners and control the process of continuous delivery of value.

\section{Concept and organization of the supply chain}

The essence of the organization and configuration of business consists of operations that create and deliver products and services, and their connection. Business organization takes different inputs (raw materials, people, information, money, etc.), perform operations (products, provides services, sales, transport, costs, the training staff), but also create products. It is a stream of materials and goods from suppliers, through production, to customers. Inputs are what the organization benefits, tangible (raw materials, semifinished products, auxiliary materials, spare parts) and intangible (information, money, knowledge). Materials range from the most distant suppliers to end customers. Among these organizations are the relations complex and interactive. The supply chain is also a range of activities and processes organized in a certain way, through which the material and intangible inputs ranging from the most distant supplier to the end customer, but the point is that these activities are linked and integrated into a single process. A special role without having logistics which is responsible for the movement of materials through the supply chain, but also for information, especially those notified of any deviations from the desired state in the supply chain. M. Christopher for supply chain process said: "This is a process which is aimed at cooperative management in order to most effectively use the resources of the distribution channels with the aim of best satisfying the consumer, and thus, achieving competitiveness (Kanji, Wong, 1999, p.1147 - 1168). In second place Christopher says that a supply chain must be serviced quickly because mistakes are costly. Manage the execution order is gear that allows the supply chain all moving smoothly (Hugos, 2003, p. 131).

During the industrial era (or traditional economy), and 50-ies of the last century competitiveness could be provided mainly through mass production, economies of scale and low production costs; barriers to competitiveness were often high capital investment. Today the competitiveness of determining performance of the demand coming from the environment and what measures the quality of products / services from the customer's perspective, speed and reliability of delivery and overall operating costs. For the most branches are more important organizational components and compliance with environmental needs, than investing in the capital. Today, due to the dynamic changes in the environment, it is difficult to predict future trends in a particular form. Therefore, there is a different approach to creating strategies: simply put strategy today generally define the basic directions of movement and the values that will be pursued, based on the capabilities that an organization owns. Businesses, in conditions of constant change 
are seeking to develop its operational capabilities and ensure the efficiency, flexibility, capability and operational excellence.

In order to overcome a number of limitations in the company, the solution is found in the establishment of in-depth partnerships with customers and suppliers, and with many service companies from which it has developed a new entity - the supply chain, which is jointly managed the entire business process, from the farthest supplier to the end customer. Through these changes the character of the given operational strategies to support basic strategic direction and competitive strategies, and numerous models, methods and management techniques, to guide business or carry out certain improvements, which have a systemic character. Competitive strategies of companies today are related to supply chain management strategies, information exchange and joint planning and joint use of resources, in order to achieve efficiency, ensure customer loyalty and competitiveness. Businesses are turning their competence where the most added value and doing what they do best, leaving all other activities, through a form of outsourcing and partnerships, other companies (Cvetković, 2016, p. 12, 17). The supply chain is also a form of organization that represents the operational response to contemporary turbulent and discontinuous and highly competitive business environment. Basically this organization is the integration and synchronization of all activities and processes of the supply chain.

In the past the company has the competitive pressures correspond to the management and improvement activities in the functional areas, departments or sectors of the company, in the acquisition, production, distribution. With growing competitive pressure control such a response was not satisfactory, primarily because between activities there is a high dependency and interactivity. Procurement Plan has an impact on inventory management, packing way to handle inventory, changes in transportation affect the operation of the warehouse. This means that an organization that can provide the best results should be linked primarily to the movement of materials, so that (in the most vital companies) come to integrate all activities input and then output logistics. Inbound logistics coordinated its activities with production plans and outbound logistics department took over all activities related to the distribution of finished products (Waters, ed., 2007, Waters, p. 4), i.e., the process of execution of orders through an integrated logistics process with internal processes. These trends in business organization have inevitably led later in the integration of all activities in the company, and then to connect and integrate the activities and processes with partners and across the supply chain. The main motive of all these integration processes is the common goal of the company in the supply chain in the most efficient way to service their relevant markets and thus achieve their business goals and business (competitive) strategy.

Today it is considered that the unique supply chain management (SCM - Supply Chain Management) is the best option for the realization of corporate strategy. The market can't compete with isolated companies, but their supply chains. This includes the harmonization of strategic goals, joint planning and sharing plans, information system shared by all companies in the supply chain, coordination and synchronization of activities. Such an integrated system supply chain is a strategic asset.

In considering the organization of the supply chain should be emphasized the importance of new information and communication technologies, as this level of efficiency of the supply chain would not be possible without its application. In doing so 
it is not just a technical tool, but also a means of creating new models of management and configuration operations.

\section{Models, methods and techniques of "time pressure"}

When it comes time pressure (time compression), it is necessary first of all to say that the selection of this strategy is not a goal to achieve maximum speed, but to achieve the ability to always perform at the time the request of customers. In this sense, time (speed) can be an integral part of the offer to customers in the market.

The weather is particularly scarce resource and an important source of competitiveness. Applying time-based, above all, means shorter delivery time. Time is an important factor from the standpoint of economy businesses because by shortening cycle times reduce costs. Time and speed of delivery are also spheres serving customers, and competitiveness, because it implies the delivery speed, the speed of resolving complaints, speed of delivery of information, and the like. "If the time is spent on non-profitable activities, then you will not have time for profitable activities." (Cox, 2003, p.18). The total time of each operation and all activities and processes together, makes the response time of the total supply chain. The companies that are working on a "production to order" (make-to-order), this time from order to delivery represents a throughput capacity. In companies where safety stock (make-to-stock "production for storage") during execution orders can be measured as the sum of time from the moment the internal order, then the time of manufacture and delivery of stock, and then adds the time from customer orders to delivery from the warehouse. Time is still controls internal efficiency, reducing downtime and costs and control the level of customer service.

Basic tasks in the implementation of these strategies focus on the time to remove processes that do not add value. That organization can be radical in the sense that this group can be assigned only processes related to the core competence of enterprises involved in the supply chain. In this case, on the other hand, can be adopted as value-added activities and those that are not essential, for example, quality inspection activities within a process, or handling of the materials within the process while it waiting for the next stage of processing. It is therefore appropriate that the second criterion is based on the theory of value chain M. Porter, which disaggregates processes in activities. According to this theory activities that add value are those that the customer is willing to pay these costs if the activity incorporated in the price. The must also be borne in mind that the activities have been removed from the process do not appear elsewhere in the supply chain, that is, an important result of the total supply chain and a holistic and systematic approach. In this regard, in some part of the process, some activities may be adding to the overall result of the process was improved, including on the basis of time because there is a high interdependence and interaction between the activities and processes in the supply chain. For example, if you pay more attention to the packaging, it can facilitate and speed up the transport or storage of cheaper, streamline processes in retail. Eliminate activities that do not add value to a company in the supply chain devote to those activities that add value. Redundant activities can be outsourced to other companies where the main activity in the form of outsourcing (outsourcing).

In search of the optimal solution must be borne in mind that any change in the process can have consequences at the time of execution, as well as the level of reserves, 
their use of resources, expenses (each activity carries its own costs), quality or level of service to customers. Tersine and Hummingbird are found (1995) that the management of the passing of time mirror quality management, cost, innovation and productivity (Waters, ed., 2007, Beesley, p. 77). In any case, the dimensions of time, in a dynamic market conditions, must always be considered, in the context and at the level of the supply chain.

Performance time (time pressure) can be supported using seven operational strategies that have been identified Carter, Mesnik and Hanfield, 1994, and today they can be applied even more in the supply chain. They are defined as: (Waters, ed., 2007, Beesley, s. 76)

- Simplification - remove from the process all the complexities that accumulate over time,

- Integration - improving information flows and communication in order to achieve an integrated information flow and operations,

- Standardization - the use of generic (reference) process model of best practice, which includes the standardization of components, modules and information flow,

- $\quad$ simultaneous operation - switch from sequential to continuous production process,

- control of process variation - prevention, in order to avoid losses in quality and time,

- $\quad$ automation of - applied to improve the efficiency and effectiveness of the organization and supply chain activities (and self-control of the system),

- resources planning - allocation of resources in accordance with the best practices of supply chain management, with the use of multi-skilled workers in order to enable the flexible use of resources (equipment).

A systematic approach to reviewing business performance, including the performance time, is incomplete at the enterprise level, since the delivery of value to customers and consumers starts from the farthest suppliers and includes a number of other partners, and ends with the final customer or consumer when you realize all the effects. Therefore, it is expedient to consider performance time in the context of the overall supply chain. Despite the complexity of the supply chain system, the current level of development of technology, especially information and communication technologies, the possibilities of combining management resources are numerous, such as the number and configuration possibilities of business, again with the use of modern information systems.

Models, methods and techniques that are used thereby have the purpose to reduce the complexity and to enable the realization of performance times, and other target performance of the supply chain. Improving performance cycle times and total time of delivery value is achieved both through the eliminations of redundant activities primarily through a creation of business processes based on the application of different models and methodologies (or concepts), and is achieved through planning, coordinating and directing the activities and processes in operational execution.

Process modeling is the initial condition for the successful management of business processes. If there is not a model of how the process is going, management will not be 
possible. When modeling system it is necessary to set up a functional part of the process, the physical flow and information flow (Hayes, 2004). This involves defining the purpose of the process and elements of technology, organization, procedures, communications and weather. Modeling the flow of data and information defines the mode of creation, a way to create databases and their use and method of exchanging data. Basically this is the flow of data between the various tasks and activities that coordinate people. This whole process is a mapping process, assuming the physical, information flows and time. The mapping process as a graphic display represents a sequence of activities and tasks and documented by a series of data in order to determine the most efficient movement of materials and goods, as well as branching information at certain points on the points which are control characters because they serve to coordinate, control and operational decision-making. Map process must include information on the status of the most important operating elements of the supply chain: cost, quality, customer service and time. The map contains the time required for the phase, tasks and activities. The map identifies the processes and activities and processes that add value, so it can be identified and the current value. The main benefit of the mapping is that it allows the visibility of movement of goods through a variety of functional areas, and therefore their usefulness. A map of the process according to define the responsibilities and the final result of the process, rather than by functional classes.

To accelerate the transformation process through the supply chain, from information on demand to procurement plans and production, it is necessary to pull the organization of activities and processes in which the starting point consists of activities related to demand management, not just plans for production and procurement of materials. The opportunities for improvement of the organization in the supply chain lies in the inclusion of employees in the process of advancing and in the application of the methodology of the JIT supply components and materials ("just in time") in the upper reaches of the chain, whose principles are applied throughout the supply chain. In the lower course of the supply chain can be applied "postponement" system, postponing the finalization until you define specific demand, after which he promptly can deliver. All these elements are the elements of lean organization. Lean manufacturing is increasingly presents itself as a lean organization system of the overall system, in which processes are triggered only when there is demand, producing only what is needed and when it is needed. This means that at each stage produces only as much as is needed for the next phase. In such a system, performance times are the basis of business organizations. Lean System also believes that the stocks of all kinds of unnecessary and should be eliminated from the process. With continuous improvements in time to eliminate potential bottlenecks that could cause delays and interruptions in the process or stockpiling.

Promoting effects usually are measured over the efficiency and the effectiveness of key processes (cycle times, costs, effects), but from the viewpoint of time necessary to measure the efficiency and effectiveness of the overall process of the supply chain. Planning, control and improvement of the supply chain improved in recent decades, many of the techniques applied in the operational process in support of the overall efficiency and effectiveness, such as, for example, (Fredendal, Hill, 2001, p.148): total productive maintenance (Total productive Maintenance, TPM), Poke-yoke, focused factories, simplification and standardization. 
Poke-yoke is mechanism and protection system that allows the prevention of errors in the use of equipment through a series of technical solutions and conditional step in using equipment. All of these techniques directly impact on the prevention of deadlock and the total time and the result of the supply chain. Simplification is done through reducing the number of activities through better distribution activities through training. Standardization and documentation of the process is essential to understand the current state of the process, to support the continuous improvement and eliminating downtime and measuring those improvements. Standardization of operations is a way to define the entry requirements, the procedure of the process, the time of each step and result. In fact, the most important reason for the standardization is to identify and understand the variations in the process and to adequately prevent or overcome delays and interruptions. The standardization process can be applied SIMPOC model that defines all elements and characteristics of the process (Supplier-Inputs-Measurement-Procedure-OutputsCustomers - suppliers, inputs, measurement, procedures, outputs, customers) (Goldsby, 2005, 233 s). Thus defined, the process leaves little room for delays and improvisation. Standardization also means reducing the number of parts and materials which are used in the manufacture of the product and modulus, as well as the definition of the types of raw material. Standardization and reducing the number of parts focus on quality improvement.

Logistics as a functional area at the level of the supply chain can make the greatest contribution to the achievement of target performance time. Integrated logistics process makes it easier to connect other processes to efficiently move materials through the supply chain in order to find where it is needed, at the right price, quantity and quality and at the right time. The components of a typical logistics system are: customer service, forecasting demand, distribution communications, inventory control, materials handling, execution of orders, support services, selection and analysis storage location, purchasing, packaging, return goods, addressing waste, traffic transport, warehousing and storage ( Council of Logistics Management) (Bowersox, Closs, Cooper, 2002, p. 55). Integrated connecting and synchronizing logistic process in the supply chain which is essential for the efficiency of the chain and weathering performance of the supply chain. One of the most important roles of logistic in the supply chain is to reduce the downtime of inventories in relation to productive time.

In recent years, talks about the agility of the supply chain or business network, whose characteristics are: market sensitivity, network organization, process integration, virtual integration. These principles are adjusted business structure and logistic processes. Commercial networks as a special form of the supply chain is created in order to effectively take advantage of market opportunities presented by more or less suddenly point. Options for this organization lie primarily in the use of highly efficient information technology and in good mutual understanding of opportunities, but basically the organization's rapid response - time dimension.

Added value entered in the inventories (in products) is associated with the length of time cycles which is adjusted to the level and dynamics of the anticipated demand. If you predict the level and dynamics of demand and supply chain has the ability to meet this schedule, inventory levels will be lower, which reduces costs and adds substantial value from the standpoint of the company. Thus, the performance time pressure and inventory model closely linked. Keeping inventories in itself causes costs for handling 
them, because of deterioration and breakage and storage costs. The added value generated for speed, compared to the industry average, it can be used to lower the prices of products and increase customer loyalty, or will affect, through a higher level of competitive price, the increase in profits of companies in the supply chain.

Time dimension of supply chain performance is associated with the dynamics of inventory levels, and then with the supply chain costs. Delivery on time (before or after the appointment) is the only correct. In the case of premature delivery appears inventory handling cost, and in case of delay appears problem stock outs, lack of supplies, which will result in different types of loss or damage.

Benefits of "time pressure" are manifold. The benefits of this strategy is first manifested in the internal framework as it reduces costs and allows the operational capacity to distinguish itself as a competitive advantage in relations with customers. However, in terms of frequent and unexpected changes in the market, the benefits of weather performance are increasing because of reduced risk for the entire supply chain: the greater the distance between making a business decision and its implementation, the ability to change circumstances and that the decision proves incorrect, all the better. It may happen that the ordered products are not sold and to create high costs for obsolete inventories, and to lose the opportunity to be the lack of (stock out) real goods occur loss due to lost sales. Therefore, the reduction of cycle time (lead time-a) delivery of strategic importance, and buyers are often willing to pay more for faster delivery. Specific advantages of the strategy time pressure are as follows (Waters, ed., 2007, Beesley, s. 84):

- Customers need a lower level of security and cyclical stocks,

- Customers are making buying for shorter periods,

- are less likely to change or cancel orders,

- increase the speed of cash flow.

It is widely known model "integrated transit" Dell company (Barac, Milovanovic, Cvetković, 2006, pp. 91-96), which is based on the best performance of cycle times and maximum customization of the product, provided it is not stockpile at any stage. The company collects on-line orders with all the performance of computers and components suppliers have adjusted their logistics platform that can deliver them in the day. Dell is thus able to deliver a computer for 48 hours. The company Cemex, Mexico, cement producer, has offered its customers the delivery of cement, not 48 hours as is standard in the industry, but for 4 hours. It is this company has turned from a regional, the other manufacturer in the world, where the organization is fully adapted to this purpose (Osterwalder, Pigneur, 2010, p. 136).

Management tools for improving performance at the same time the weather impact on system performance because stock levels between these performances there is a high interdependence and interactivity. Model of inventory management by the vendor (Vendor Managed Inventory, VMI) model and joint planning, forecasting and filling (Collaborative Planning, Forecasting, and Replenishment, CPFR), dramatically shorten the procedure of delivery and filling, reduce inventory levels without compromising service levels. 


\section{Models, methods and techniques of inventory management in supply chain}

High inventories often cover many shortcomings in the organization and functioning of the supply chain, the structural and operational level. "Doing business without supplies," provided that it meets the demand for efficient, reliable sign that the organization is good.

The most important organizational goals are to increase supply chain flexibility for the demand that is continually changing and improving the quality and level of service to customers (mix of products and services). The other two targets, reducing inventory in the supply chain and lessening the overall supply chain costs seem to be able to reduce the level of services. The concept of supply chain allows it to be so. Inventories only mask the problems and mistakes in the organization and in principle are unnecessary. Business "no stock" indicates that the supply chain is well organized, that all flows are aligned and synchronized; they established a real partnership and implemented adequate management models. To all these organizational control objectives, it is necessary to cross measuring the level of inventories, supply chain costs and service levels.

The basic model is the result of tracking stock (records) and accounting laws of motion of material (Ryzen, 1998):

\section{Inventories $=$ cumulative supply (procurement) - cumulative demand.}

In other words, if we draw a black box around the portion of the supply network and measure the total quantity of product which flows into the box (supply), and then subtracting the total amount of which determine that out from the box (demand), the result of the stock in the box, provided it is not an item is destroyed on the road. The mathematical formula is:

$$
\text { I (t) }=\mathbf{S}(\mathbf{0}, \mathbf{t}]-\mathbf{D}(\mathbf{0}, \mathbf{t}) \text {. }
$$

Inventories in the supply chain consist of basic and safety stock. Base is usually at the level of half of the usual delivery for the reference period. Safety stocks as protection against variations in demand or variations of operating a lead-time. They are the hubs or between, the bonds that achieves logistics. Inventories are stored when necessary or underway between nodes, requiring different handling, which raises costs.

I ( $\mathrm{t}$ ) means a specific stock in the box at the time $t$, and it is assumed to be started without the stock in the box at a time $\mathrm{t}(\mathrm{I}(0)=0)$. The result may be negative, if customers buy goods and not received by the edge of the time $(\mathrm{I}(\mathrm{t})<0)$, i.e. demand exceeds supply. Positive stocks can be thought of as the amount of a pending order, and negative orders that await edge.

Since it is in practice impossible to establish a lasting balance between supply and demand, it is necessary to know what causes it, to understand the appropriateness of the cost of inventories and inventory to be managed. Sam management model inventory levels and inventory costs include consideration of determinants such as ordering and procurement costs, the costs of holding and handling inventory, lead time (time series) procurement lead time delivery to customers, the cost of stock-out (lack of goods). Through the model is actually considered, on the one hand, expenses, on the other hand 
features and service levels through a system of inventory supply chain. Time in the model included the relations of coordination, policy reserves, timeliness of information exchange, responsiveness to customers and required (competitive) level of service.

Since keeping inventory costs money, you need to find the optimal level and determine the reorder point. In the traditional economy, the key question is any quantity produced, i.e., scale economy-sized production series (EBQ, economic batch quantity), while today, the JIT system, the more important question of what amount of raw materials to order and when to order, i.e., bit the scale economy in size (volume) as the material ordering (Economic order quantity, EOQ). That is, when produced for stock and in large quantities when the costs of preparing for a new production line were high, it was essential compensation (trade-off) between the cost of preparing a new series of machines for production and inventory carrying costs required for smooth production. The essential operational flexibility is achieved through actually speed adjustment lines (equipment) for the new production series. Today it is often used flexible equipment based on electronics which is being prepared for production measured in minutes.

Today, in terms of pull organizations, small batches, frequent delivery and JIT system, when the weather is preparing reduced to minute, economical ordering of materials is seen in relation to the dynamics of demand, but not with respect to production. It is necessary, in terms of the specific dynamics of demand, to find the optimal point on the scale economy and the balance between the frequency of ordering, the costs of ordering and inventory handling costs, then, to determine the level of basic security and inventories in relation to the planned level of service to customers (Cvetković, 2016, with 152).

In addition to reducing costs, there are other, more important goals of eliminating or reducing inventories, and to the goals of improving the overall system efficiency and saving other resources in the supply chain. In inventory management, you need to know what causes the stock to the changing organization of activities and processes conducted or structural changes in the organization of the supply chain.

The level of the stock along the entire supply chain (raw materials, intermediate products and finished products) is one of the key performances of the supply chain, which has high operational, as well as strategic implications. The level of stocks is a measure of efficiency, effectiveness, quality and service levels. There are four ways you can positively affect the level of inventories, respectively, to reduce the level of safety stock (Scott Lundgren, Thompson, 2011, p. 16):

- Shortening of lead-time,

- Reducing uncertainty on the supply side,

- Reduction of errors in forecasting demand,

- Reducing the level of service (customer supplied).

By shortening the lead-time and the supplier can largely eliminate the security stocks provided that demand is known. In this sense, a good forecast of demand is the key to reduce inventories. However, we can add a fifth factor - integration relationship with customers and suppliers. The high level of integration and cooperation of the supply chain to actually sustained ability to synchronize activities and the elimination of "whip effect" - disturbances in the supply chain of the market and the stockpiling of various points in the distribution chain, but also a lack of goods to the other points. 
One of the most important reasons for the integration of the supply chain is the construction of these key competences to permanently reduce downtime stock in relation to the productive time. To achieve such synchronization, except for demand forecasting and related integration with suppliers, it is necessary that the logistics function is fully integrated into the operating system of the total supply chain.

In order to improve integration of the respective operative and in the supply chain can be used to manage these relationships models such as model inventory management by the vendor (VMI), and model of common plan, forecast, and the filling (CPFR). These are the models that govern relations between buyers and suppliers and supply process, but that process can determine the dynamics of the overall supply chain. These models shorten the exchange of information, simplify procedures and eliminate a number of transactional activities, reduce inventories and costs at all stages of the supply chain, without compromising service levels. Since there is a high level of exchange of information, customer service (fast, complete and accurate delivery) can be always at the optimum level.

VMI model is suitable for consumer goods. The essence of the VMI model is to eliminate stock-outs - and the lack of materials in the production and finished goods to fully satisfy real demand. Inventories are being pushed towards the suppliers of raw materials, a manufacturer and retail work after the pull system. This model is very useful for suppliers of raw materials because they are constantly aware of the current, live market information, thereby gaining valuable experience and alertness and thus were able to reduce their own inventories. Model also has its full effects on the supply side.

CPFR model is more complex and involves more comprehensive analysis and is suitable for use in the upper reaches of the supply chain (between the suppliers and manufacturers). CPFR is a model that allows supply chain partners to share historical data and develop plans of production and distribution for the future. This model makes it possible to determine the need for products for normal operating conditions, the promotional periods or not planned altered level of demand for other reasons. With the help of information being shared are defined stock levels and terms of completing the procedures in the special situation of the market. The model contains a system of collecting data on the demand of finished products directly to the market, retail, and then the data is combined with other data related to information and elements of the strategy stocks to fill in order to support the common prediction and a common business plan. This makes it possible to reserve production capacity sufficient to meet demand to minimize safety stock and at the same time retailers are sure to be filled orders (Blanchard, 2010, p. 165.)

Using these models can be proved that with the reduction or elimination of the stock can increase the level of service to the customers, and the total efficiency of the supply chain.

The company that produces furniture IKEA has 1,800 suppliers in 50 countries, 9,500 products, 345 stores in 42 countries, 36 distribution centers in 16 countries, 1,500,000 million deliveries and 35.5 million in revenue. IKEA with its suppliers sign a code of cooperation that are based primarily low cost, environmental performance and corporate social responsibility (Milovanovic, Milovanovic, Radosavljevic, 2017, 35). IKEA based their cooperation on longterm planning, at least 5 years, starting from the possibility of the supplier, the capacity and quality of raw materials suppliers can offer. The company, in its retail stores allows customers to combine themselves and seek solutions for your furniture with the support of experts IKEA (https://rctom.hbs.org/submission/ikeas-business-and-operating-models-a-matchmade- and-heaven /). Combining their information from the market with the capabilities of 
its suppliers, IKEA with them practically implemented CPFR model, but also a model of delayed installation because with carefully researched customer needs offers a number of alternatives for solving the housing problems of customers in the store. This is an acceptable level of inventories solve almost all customer needs and provides the principles of mass customization principles and reducing inventories. In this way the amount of inventories is reduced "because it is a function of the square root of demand": if demand doubles, inventories will increase only for the square root of 2 (1.414). (Fredendal, Hill, 2001, 140).

\section{The necessity of changing the management practices of companies in Serbia}

Management practices in Serbian companies do not know enough of modern management tools, in addition to companies that are connected through the acquisition of global business systems. Serbia has experienced deindustrialization dismantling and deterioration of large business conglomerates. Restructuring did not produce results because they are most often made without a clear objective, commitment and competence. Thus, it is not built a new management practice, where of course there are the few exceptions that do not have the "critical mass" for visible changes in the business and management practices. In doing so, companies sold large systems as a rule are closed for business and the general public in order to allow a broader introduction to the practice of their organization and management.

Managers and businessmen from Serbia need to understand the new strategic approaches, partnerships and flexible organization and operational solutions that bring efficiency and competitiveness, and the necessity of building pithy competence, character information and other technologies, the need for learning. All these elements are included in the concept of the supply chain.

One example of successful privatization in Serbia and successful integration into global supply chains is the pharmaceutical industry "Zdravlje" Leskovac: ${ }^{4}$

Privatization of enterprises for the production of drugs, "Zdravlje" Leskovac in 2002 was a classic acquisition. "Zdravlje" as a successful company in the past, relatively easily and successfully incorporated in the system Actavis group (former name Pharmaco), a system of inter functional coordination, including improving the system performance to a system in the company fit. In a few years after privatization Actavis is in this transitional period, invested by 200631 million euros, so that the system was able to be compatible with the corporation. It has invested in new equipment for the production, in the adaptation of production and warehouse space, the new information system (SAP), in quality control and improvement of working conditions. SAP, the operating system is modular and consists of 11 modules, and the "Zdravlje Actavis" (up to 2014) implemented 7: materials management, finance, control, quality management, sales and distribution module and human resources (HR). As a special, strategically significant investment in 2005 highlights the age adaptation PJ "Pharmacy" and warehouses that have been reconstructed in accordance with the highest standards of good storage practices.

4 https://www.lakemedelsverket.se/.../part2\%20nr3, and according to the information (and documentation) of the interview with the directors of "human resources" and "logistics" of Zdravlje, in 2014. 
Immediately, after the privatization of "Zdravlje" removed the non-core activities: Factory tube and dose in Lebane is sold, canteen, transport and operation provided cosmetics to partners in the form of partners who are for the account of "Zdravlje" engage in such activities by outsourcing system. Under the system of outsourcing is regulated and maintenance and cleaning.

In the "Zdravlje" has been fully implemented corporate business model Actavis, as a model and control performance quality, PDCA loop, which strongly determines processes (Figure 1). Actavis management system in a corporation that is implemented in the "Zdravlje" is set in accordance with the standards for the preservation of a healthy environment and human health and safety (EHS - Environmental Health and Safety Management System). Through this model realizing the integration of the Actavis system control through the following processes:

- equalization of documentations,

- defining objectives,

- installation of standards and performances (and verification, measuring the embodiments),

- system of continuous improvement.

Unification of documentation is generated decoration forms and flow of documents with the help of information systems and information technology best, both horizontally and vertically to the top management of the corporation. Strategic corporate values and objectives are implemented in the "Zdravlje" of the tactical objectives and the operational activities in the process. All the objectives of the "Zdravlje" are set in accordance with the corporate values, legal requirements, technologies options, financial, operational and business requirements. At the same time the goals are defined and responsibilities for the processes necessary actions to achieve the objectives and deadlines, which is also subject to continuous review process.

The objectives are reviewed periodically through key performance indicators, as well as organizational development (organizational charts, job descriptions and resources). Part regular communication procedure in the "Zdravlje" and the corporation are reports (local business unit management and regulatory bodies, corporations) and committee sessions, meetings and interviews.

In the new conditions in the system Actavis emphasized the aim is to produce "Zdravlje" that the markets are delivered on time and where it is needed. At the same time from the corporation through a new organization implemented an aggressive approach to cost reduction. Developing partnerships is carried out according to the criteria features: 1) to reduce costs and increase efficiency, 2) to bring new products to new markets continuously flows through the stable supply. "Zdravlje" is also trying to get into the whole system "to develop a dynamic corporate culture of commitment, compliance, motivation and active involvement of hardworking people who are willing to participate in increasing efficiency and achieving goals, including fully into the business process. Speed and flexibility in relation to demand are basic operational performance in order to achieve the strategy.

The business model of "Zdravlje" is trying to take advantage of the Actavis corporations system. These benefits arise from the performance as:

a) The effective technology transfer (through all parts of the corporation)

b) The effective knowledge management, 
v) Harmonization of documentation,

g) The rational use of resources, and

d) The efficiency of prioritizing and their transfer through the corporation.

Procedures, and the organizational structure of the constant can be challenged and which may be at the initiative of the PE, which can affect the return and to the general procedure and the improvement at all levels. This eliminates the risk of negative effects of centralization of decision-making, which may lead to a recession and loss of resources. Planning is adapted discontinuous conditions. Operational Planning in Zdravlje Actavis-in takes place after the system rolling forecast (rolling - sliding forecasting demand and production), yet for 12 months, with a defined schedule and monthly schedule for the next month, with the precise structure and terms, in accordance with customer needs. Plan to innovate every month for the next 12 months. The sales plan (which is the production plan) creates marketing sector sales department. Marketing plan makes this class of planning in the production where I give a production plan, with full implementation of the MRP II (Manufacturing Resources Planning). At this stage in the planning, through the SAP system, involved other functional areas - finance, engineering, procurement and human resources. Logistics sector which manages the procurement of necessary materials to complete the monthly plan, which is defined at the level determined by demand, according to the procedure specified module procurement. About $70 \%$ of procurement procedures carried out by the methodology just-in-time, or supplied when there is demand, when run production processes. The system just-in-time is applied is limited. Supply and transport (by outsourcing system) are the responsibility of the logistics sector.

Figure 1: "Zdravlje Actavis EHS" - cycle control performance - PDCA loop, model control performance corporation Actavis implemented in "Zdravlje"

\section{Actavis EHS - Performance Control Cycle / PDCA loop}

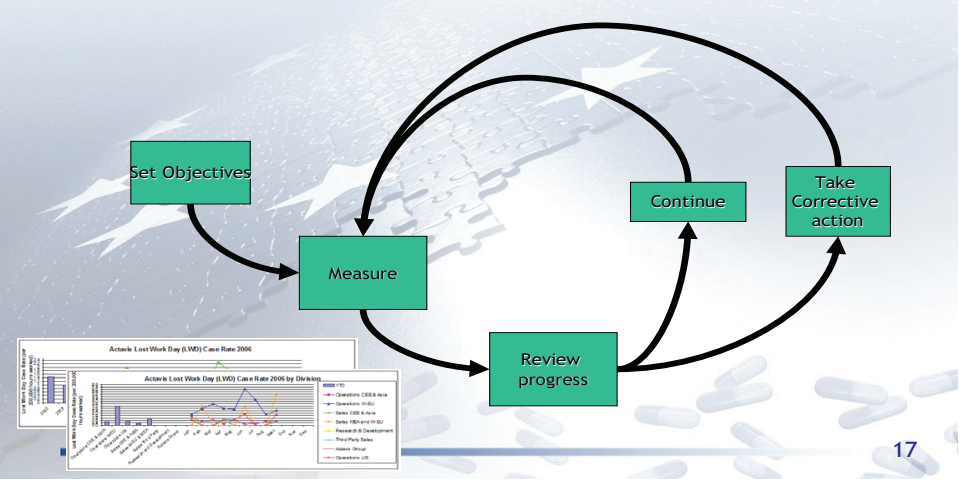

Source: https://www.lakemedelsverket.se/.../part2\%20nr3 
All activities are entered into the SAP system in real time (thereby forming the documentation), so that in the process no unnecessary steps even skipping activities. The system of identifying the perpetrator (the principal) of activities enables additional control after a long time.

Within the manufacturing sector of Health was formed "customer service" department whose task (through marketing) to address specific issues and requirements of customers. This is a dynamic communications with the market and a valuable source of information.

In the period before the privatization of the company Zdravlje has worked in the system of mass production (build to stock) and "push" products on the market (push system). Today it effectively applies the system of "drawing" of a product from the market and customers (pull system). Zdravlje Actavis is in line to achieve its competitive strategy based on the following criteria: 1) Operational excellence (responsiveness at low cost), 2) trust of customers, and 3) leadership in products (continuous product innovation). Continuous communication within the company and with the environment is the basis of continuous learning and creativity.

Positive effects of the seven-year transition effort, involvement of "Zdravlje" in Actavis Group can be illustrated by the following data:

- efficiency is improved, delivery lead time is shortened from two months to a few days,

- increased annual revenue from 45 to 71 million euros in 2009,

- export is increased from $16 \%$ to $46 \%$ in 2009 .

- $70 \%$ of the procurement system is carried out by "just-in-time" system.

Also, many times the increased capacity is planned that production in the next period to increase from 500 million to 1.9 billion tablets, whose sale is provided through a system of Actavis in the world market, thus all other performance dramatically improved.

And the planning and organization of the operating system in the "Zdravlje" are essentially facing accelerating the process, shortening cycle times, quality control, inventory reduction and cost reduction, while the achievement of a high level of customer service. A special role in achieving these goals is the information system.

It could be said that the period of transition in Serbia takes a very long time that one of the reasons for insufficient knowledge of current management practices and modern strategic approach and organizational solutions in global business. State investment in such projects, education would be the least that can be done. Results could be called that many small and medium enterprises to become successful and become a promising, able to engage in global flows and supply chains. Some of them might even become a significant internationals or global companies.

\section{Conclusion}

Modern environment and business conditions in recent years have led to the need for radical changes in the business organization. With the change in the strategic focus on the needs and requirements of customers and consumers became necessary changes in the organization of business functions in the process. This has led to the 
development and application of the concept of the supply chain as a response to the present operating conditions. The supply chain is characterized deepened, partnerships and process structure of the business organization. Many research and practice prove that the market compete integrated supply chains, rather than isolated companies. Management of the supply chain is carried out through a common management of organizational performance and performance of activities and processes overall supply chain. In considering the organization of the supply chain should be emphasized the importance of new information and communication technologies, which are not only a technical tool, but also a means of creating new models of management and configuration operations.

Key performance supply chain performance is the flexibility and resources of the organization, in order to respond to constant changes in the market. However, there are performances that are seemingly contradictory with key strategic goal - satisfaction of customers and consumers. This performance is the speed (time pressure) and performance levels of inventories (reduction or elimination of inventories).

When it comes time pressure (time compression), it is necessary first of all to say that the selection of this strategy is not a goal at all costs to achieve maximum speed, but the ability to achieve speeds that are always on time, carry customers' requirements. In this sense, time (speed) can be an integral part of the offer to customers in the market. Applications on the basis of time involves primarily shorter delivery time, but with the new operating strategies and lean organization where processes are triggered if there is demand, delivery time is associated with upstream processes, the cycle times of the whole process of the supply chain. The main task in implementing these strategies focus on the time is to remove the activities and processes that do not add value. Models, methods and techniques that are used while their purpose is to reduce complexity and enable the achievement of performance times and other target performance value chain, as well as quality. Map process as a graphical representation must contain information on the status of the most important operating elements of the supply chain: cost, quality, customer service and time. The map identifies the processes and activities and processes that add value, so it can be identified and the current value. In lean organization is applied to pull the organization of activities and processes, just-in-time ( "on time") in the upper reaches of the supply, delayed assembly in the lower courses of the supply chain. In the process of manufacture are used techniques that are supporting the continuity of the overall process has to productive equipment maintenance, Poke-yoke, simplification and standardization. The movement of material through the processes of logistics has a special role, which must be integrated into the operational process of the supply of chain. The benefits of this strategy is first manifested in the internal framework as it reduces costs and allows the operational capacity to distinguish itself as a competitive advantage in relations with customers, allowing them to reduce stocks and to secure supply. At the same time accelerate cash flows. In this sense, applied management models in the supply chain, such as inventory management model by the vendor (VMI) model of joint planning, forecasting and filling (CPFR), dramatically shorten the procedure of delivery and filling, reduce inventory levels without compromising on quality and the level of service. These models are an integral part of inventory management model.

High inventories often cover many shortcomings in the organization and functioning of the supply chain, the structural and operational level. "Doing business 
without supplies," provided that it meets the demand for efficient, reliable sign that the organization is efficient. Inventory management is not just accounting issue, but the object and competitiveness strategy and operating strategy. As a strategic issue is associated with the level of service to customers, and as operational services to customers and the cost and operational efficiency, while appearing contradictions that are the subject of this paper. This contradiction is solved through the achievement of performance "operational excellence" which drastically reduce or eliminate inventories without compromising service levels. The condition for the achievement of such performance is primarily the ability to forecast demand (primarily through the continuous exchange of information), and then implementing a strategy of pressure and time synchronization of the overall process. In this respect, apply and models for managing relationships and directing the activities and processes in the supply chain - VMI and CPFR.

The final conclusion is that the contradiction between the time pressure and the elimination or reduction of inventories, on the other hand, the quality and level of services can be solved only by efficient operational processes, and principles of business and operational excellence that are based primarily focus on customers, flexibility, shorter time cycle, integrated information system and a high level of integration activities and processes.

In order to improve competitiveness, it is essential that managers and businessmen in Serbia acquainted with modern management practices in the world.

\section{References}

Kanji G. K., Wong A. "Business Excellence model for supply chain management", Total Quality Management, Vol.10, No. 8, 1999, 1147 - 1168.

Hugos M., „Essentials of Supply Chain Management“, John Wiley and Sons, Inc., 2003.

Cvetković M. "Creating and developing a system of performance measurement activities and processes of companies in the supply chain.", Doctoral dissertation, Faculty of Economics Niš, 2016.

Waters D., ed., „, Global Logistiks - New Directions in Supply Chain Management“", Kogan Page, Fifth edition, 2007., Waters D., „Trends in the Supply Chain“, p.120.

Cox A., Ireland p., Lonsdale C., Sanderson J., Watson G., „Supply Chain Management“, Prentice Hall, Financial Times, 2003.

Waters D., ed., „, Global Logistiks - New Directions in Supply Chain Management“, Kogan Page, Fifth edition, 2007., Beesley A., "Time compression in the Supply chain", p. 72-90.

Hayes H., „The Value of Business Process Modeling and Analysis“, White Paper, January 2004.

Fredendal L. D., Hill E., „, Basics of Supply Chain Management“", CRC Press LLC, USA, 2001. 
Goldsby T., Martichenko R., „Lean Six Sigma Logistics“, J. Ross Publishing, Inc., U.S.A., 2005.

Bowersox D., Closs D., Cooper Bixby M., „Supply Chain Logistics Management“, McGrawHill, Inc., The International Edition, 2002.

Barac N, Milovanović G., S. Cvetković, "Strategic flexibility and adaptability of logistics", Serbian second seminar 'Til 2006 ", Proceedings of Mechanical Engineering, Niš, 2006, p. 91-96.

Osterwalder A., (2010), Pigneur Y., „,Business Model Generation“, Yohn Wiley and Sons, Inc., Hoboken, New Jersey.

Ryzen van G., „Supply Chain Management, Analyzing Inventory Cost and Service in Supply Chains", Columbia Business School, Decembar 1998.

Scott C., Lundgren H., Thompson P., „Guide to Supply Chain Management”, SpringerVerlag Berlin Heidelberg, 2011.

Blanchard D. „Supply Chain Management, Best Practices“, John Wiley \& Sons, Inc., 2010 .

Milovanović G, Milovanović S., Radisavljević G., (2017), „Globalization - the key challenge of modern supply chain“, Ekonomika, Niš, Vol. 63, january-march 2017, № 1 pp. 31-40.

https://rctom.hbs.org/submission/ikeas-business-and-operating-models-a-matchmade-in-heaven/, (Accessed 06 May.2017)

https://www.lakemedelsverket.se/.../part2\%20nr3. (Accessed 06 May 2017) 
